\title{
ANALYSIS OF THE HUMAN FACTOR IN AIR ACCIDENTS IN POLISH CIVIL AVIATION IN THE YEARS 2010-2015
}

\author{
Justyna SKRZYŃSKA ${ }^{1}, Z_{\text {Zdzisław KOBOS }}^{2}$, Zbigniew WOCHYŃSKI ${ }^{3}$ \\ 1 Students Association - Psychophysical Preparation for Flights, Polish Air Force Academy, Dęblin, Poland \\ 2 Chair of Occupational Psychology and Stress, Cardinal Stefan Wyszyński University, Warsaw, Poland \\ 3 Department of Physical Education, Polish Air Force Academy, Dęblin, Poland
}

Source of support: Own sources

Author's address: Z. Kobos, Cardinal Stefan Wyszyński University in Warsaw, Institute of Psychology, Wóycickiego 1/3 Street, building 14, 01-444 Warsaw, Poland, e-mail: z.kobos@uksw.edu.pl

Abstract: Air accidents are inherent to aviation, regardless of the level of advancement of aviation technology. Both at the stage of aircraft construction and production, as well as during their operation, there are both failures of technological solutions and their handling by ground services or crews during air missions. At each of these stages, different tasks and activities are carried out by a person who may contribute in the short or long term to the inefficient operation of the system: crew - aircraft - environment (C-Ac-E) [17] that resulted in a catastrophe or air accident. The analysis of accidents often focuses on the impact of the so-called human factor on the causes that led to the accident or catastrophe.

The aim of the paper was to analyze the most frequent causes of accidents as a result of the human factor. In order to achieve this objective, the available documentation of 210 civil air accidents that occurred in the Polish airspace was analyzed. Among the examined accident records for the years 2010-2015, the cause of the majority of accidents was the so-called human factor, which accounted for $80 \%$ of all unfortunate events.

Keywords: aviation, human factor, stress, accidents and catastrophes 


\section{INTRODUCTION}

People have always dreamed of going up in the air, mainly because of the correlation between flying and the sense of freedom and the range of possibilities that could be opened up to them. The first descriptions of attempts to rise above the ground can be found in the ancient legend about Daedalus and Icarus. From this legend we learn that the human factor, in this case disobedience or excessive fantasy, was the cause of the catastrophe. However, such a message did not stop mankind from further attempts to rise above the clouds. Kites that could carry people, first prototypes of helicopters made of bamboo, hot air balloons and even prototypes of parachutes have been built across the ages.

Already in the fifteenth century, after many years of observing birds flying, Leonardo da Vinci designed and described in detail the first flying machines, such as: ornithopters (fig. 1), gliders, aerial screws or parachutes [8].

In 1783 the first demonstration of Montgolfier brothers' hot-air balloon took place (fig. 2), and gliders have been in use since 1883.

However, the actual beginning of aviation is assumed to be the first flight of an airplane with an engine, which was carried out by the Wright brothers (fig. 3). It took place on December 17, 1903 and allowed to traverse the distance of 36 meters and lasted only 12 seconds [8]. To sum up, it can be said that each of the methods of flight is more than 100 years old.
In the 20th century, people's requirements for the execution of flights rose sharply. People wanted to spend more and more time in the air, move long distances and afterwards land safely. It was then that the boom in the development of aviation began. And so, in 1969, man managed to land on the moon. This success was made up of many elements, such as the incredible technological development before and during the Second World War. Already then, attention began to be paid to the abilities (psychophysical capabilities) of the human body associated with the effective performance of tasks in the air. After the end of the Second World War and during the Cold War, the military began to examine the ability of the human body to cope with high-G, to receive information and to control the level of spatial and geographical orientation. It turned out that the technological development of aircraft construction and their operational capabilities were ahead of the pilot's capabilities of effective operation. At the beginning of the 20th century, for every 2 catastrophes caused by human error there were 8 catastrophes caused by technical problems. In the 1970 s, this ratio was practically reversed $[2,4,8,10]$.

It was the military aviation during the Second World War that began to pay attention to the ergonomics of aircraft, as well as the appropriate procedures for training pilots. At present, both military and civil aviation have a wide database of aviation events (incidents, accidents and catastro-

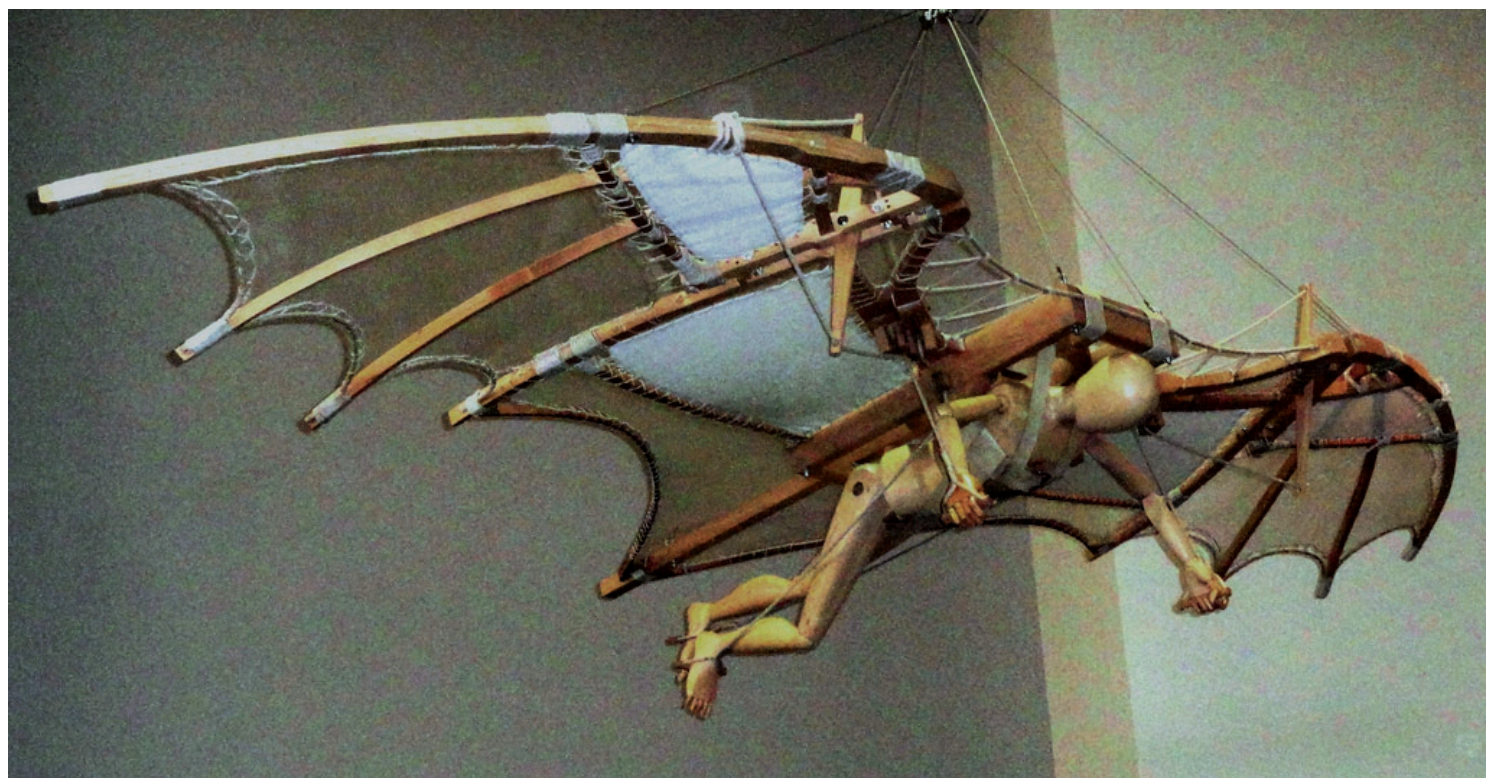

Fig. 1. Model of Leonardo Da Vinci's ornithopter (Source:http://www.katalogmonet.pl/Katalog/Pieni\%C4\%85dz-zast\%C4\%99pczy/ll-RP-\%C5\%BBetony/\%C5\%BBetonypami\%C4\%85tkowe/19873-20-ornitopter\%C3\%B3w-Leonardo-da-Vinci-WZORZEC-PRODUKCYJNY-DLA-MONETYPR\%C3\%93BA-mied\%C5\%BA-patynowana-dp2). 


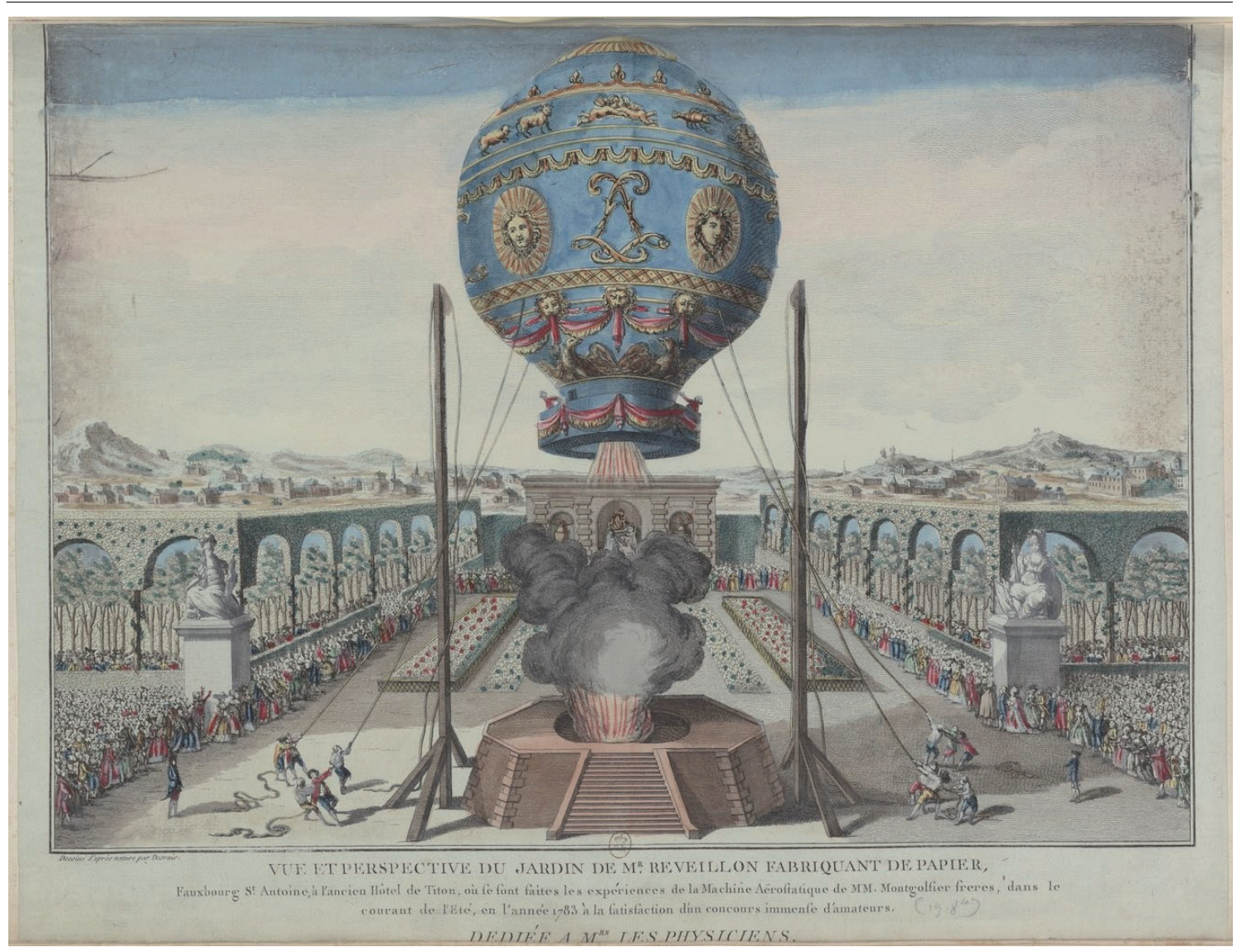

Fig. 2. The Montgolfier brothers' balloon

(Source: https://www.google.com/search?client=firefoxd\&channel=trow\&tbm=isch\&sa=1\&ei=TY5nXeqvGeWk rgT_2JHIBg\&q=balonu+na+gor\%C4\%85ce+powietrze+braci+Montgolfier\&oq=balonu+na+gor\%C4\%85ce+po wietrze+braci+Montgolfier\&gs_l=img.3...459966.459966.471199...0.0..0.55.55.1..........2j1..gws-wiz-img.M71 kr1 PKAGY\&ved=0ahUKEwiqivOY1qfkAhVlkosKHX9sBGkQ4dUDCAY\&uact=5\#imgrc=gleLw6zgxx9jaM:).

phes), the analysis of which may enable preventive actions to be taken and thus prevent the occurrence of further accidents [2].

In Poland, in the years 2010-2015, there were on average 33 accidents per year, while in the United States there were about 1000 accidents, whereas the percentage share of accidents in the number of air operations is very similar and is still decreasing. In addition, it is worth mentioning that there are far more accidents in private air traffic than in commercial air transport, where pilots are much better trained and airlines make every ef-

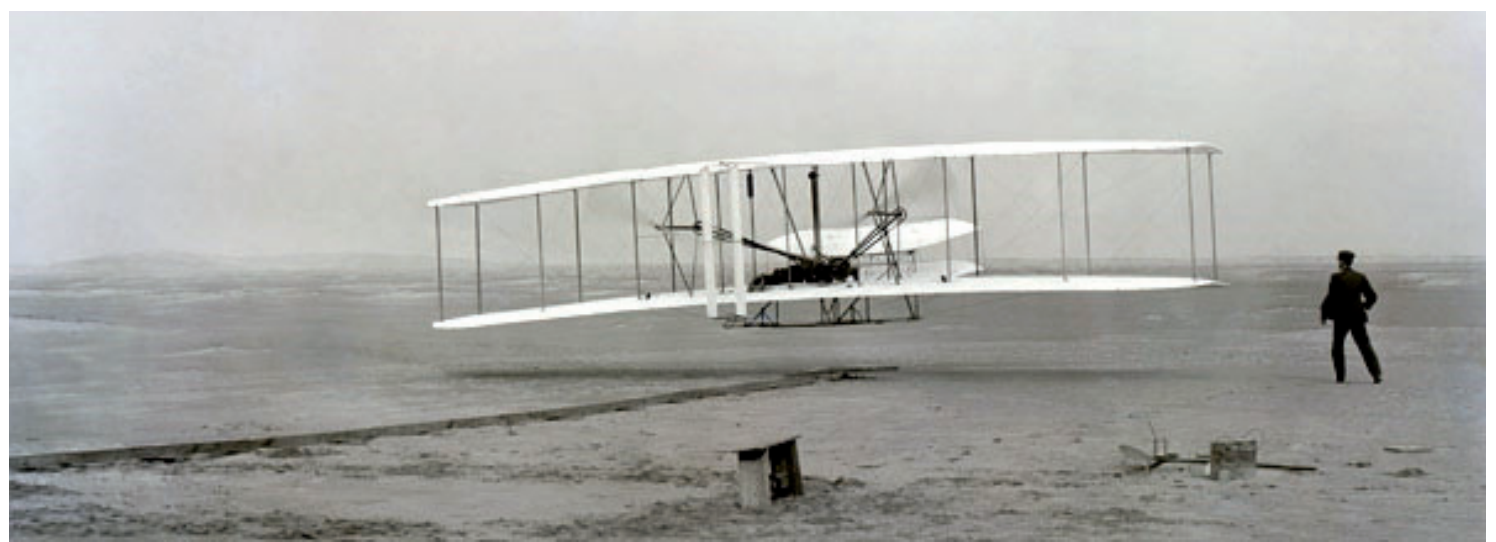

Fig. 3. The Wright Brothers' machine

(Source:https://www.google.com/search?q=si\%C4\%99+pierwszy+lot+samolotu+z+silnikiem,+kt\%C $3 \%$ B3ry+zrealizowali++braci+Wright\&client=firefoxd\&channel=trow\&source=Inms\&tbm $=i s c h \& s a=X-$ \&ved=0ahUKEwig2e2a3afkAhVq-yoKHUneDpwQ_AUIESgB\&biw=1680\&bih=936\#imgrc=rQjo46tHpqdJCM:). 
fort to ensure the safety of the services provided $[5,7,11,12,15]$.

The causes of these accidents or catastrophes are usually numerous, but most frequently they are caused by people who constructed the flying apparatuses, operated it, or are flight organizers or crew members. Each of the above causes results to some extent from the so-called human factor and usually indicates the unreliability of the activities or tasks performed by man, at different stages of the functioning of the functional system, i.e. crew - aircraft - environment (C-Ac-E). Thus, we can speak of the following risk areas depending on the above factors:

- human (unreliable operation determined by physical condition, mental fitness, current psychophysical well-being),

- technical (design errors, defective materials, failure to observe production regimes, inspections, maintenance, operation, etc.),

- legal and organizational (non-observance of rules for the use of aircraft equipment and flight organization),

- social environment (family, task force atmosphere, crew line-up in a given flight mission, organizational climate),

- random activities independent of those mentioned above.

Therefore, in the context of aviation, we can speak of the following types of errors resulting from unreliable human activity, which may lead to unreliable flight crew activity. These are the following types of errors: cognitive, ergonomic, design, aerodynamic, psychosocial, organizational, health errors.

These errors have different characteristics and origins, and have a negative impact on aviation incidents. They have specific effects that can be eliminated or preventive action can be taken.

In addition, it should be stressed that aviation events tend to have a high media impact and attract public interest. Therefore, the causes of accidents in the public perception are first sought in the area of the human factor, i.e. the errors made by the aircraft crew. These errors may or may not be attributable to the crew and may be due to: the specific nature of the task, the operability of the equipment, the meteorological conditions, the training conditions or the organization and coordination of a specific task by ground-based flight control and safety services (Air Traffic Service, Flight Information Service).

The most common cause of air accidents is, however, the errors that accumulate at a certain point in time and place. Then, there occurs the so-called domino effect (a metaphor used to describe a situation in which one small event triggers a series of consecutive events that cannot be stopped because they result from one of the other events), which was proposed by the leader in safety research, pilot and psychologist James T. Reason (fig. 4). This researcher was a psychologist at the Royal Air Force (RAF) from 1962 to 1964, conducting research at the Institute of Aviation Medicine in Farnborough and then at the US Naval Aerospace Medical Institute in Pensacola, Florida. Then, from 1964 to 1976, he was an assistant lecturer, lecturer and researcher at the Psychology Department of the University of Leicester [14].

\section{Reason's Swiss Cheese Model}

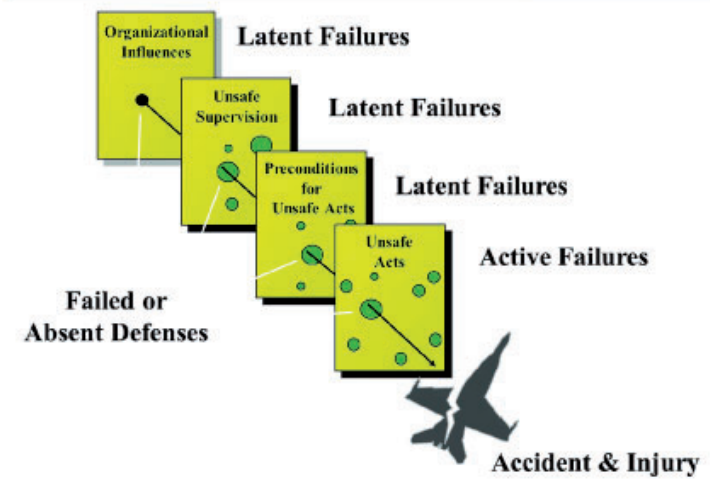

Fig. 4. James Reason's model of the occurrence of an aviation accident (Source: https://www. researchgate.net/figure/Reasons-SwissCheese-Model_fig4_303364455).

This author claims that there is always a root cause that triggers a series of adverse events and, as a result, usually leads to an accident. According to Reason, this root cause is the predisposition of man, preferring to take dangerous actions. However, it seems that the assumption that risky behavior is an immanent feature of a person is a rather simplified explanation of the causes of accidents. On the other hand, literal application of the above model in preventive actions would mean the creation of a series of prohibitions and bureaucratic barriers that would allow the tasks to be carried out only in very idealized conditions, and even sometimes would make it impossible to carry them out effectively.

However, it should be borne in mind that aviation, especially military aviation, sports aviation and sometimes even civil aviation, operates very often in extreme situations.

Therefore, the occurrence of accidents in aviation should be looked at holistically, taking into account many negative factors which have a synergistic effect on the course of flights and, in the 
end, may contribute to an accident or catastrophe. Therefore, such an analysis should also take into account the previous: accident premises (situations that occur frequently and create an accident hazard, or may sometimes lead to an accident), accident incidents (events that caused a strong, subjective sense of safety risk, or serious incidents (situations that could have led to an accident or disaster, but thanks to a happy coincidence of different circumstances it was possible to avoid an extreme event).

It seems that only such a broad approach to the investigation of accidents and catastrophes in aviation gives the commission an opportunity to investigate such events and to explain them reliably, pointing out the comprehensive reasons for the impact of:

- the human factor at the stage of manufacture, overhaul and preparation of the aircraft for the mission,

- pre-flight assessment of aircraft and efficiency of operation of individual aggregates, pilotnavigation devices during flight,

- mission planning,

- the meteorological conditions,

- the control and coordination of the flight,

- the efficiency of the crew,

- the psycho-physical condition of the crew before and during the execution of the flight,

- other factors that could not have been foreseen. A similar opinion is shared by David Beaty, a psychologist who is also a pilot and a writer, author of the cult book "Naked Pilot: The Human Factor in Aircraft Accidents" [2]. Based on his experience as a pilot, he makes a psychological analysis of the mistakes made by the aircrew. He also points to the fact that human errors are most often due to individual characteristics of a given person, but are also conditioned by many other elements, often independent of the flight crew.

Moreover, the development of information sciences and mathematical modeling, especially artificial neural networks, provides an opportunity to approximate and explain accidents or air disasters in the aforementioned holistic approach.

Among the generally understood formulation of the human factor, we can also distinguish the following conditions that may lead to aviation disasters, i.e.: fatigue, distraction, poor assessment of the situation, stress, age, illness, medication, current bad psychophysical condition of the body, family and professional problems, etc. In addition, bad nutrition or malnutrition as well as incomplete sleep or sleep deprivation may also have a nega- tive impact on the psychophysical performance of the pilot in flight.

In order to assess which factors had an impact on air accidents during this time period, the following analysis was made. The aim was to identify the most frequent causes of human factorinduced air accidents in civil aviation.

\section{METHOD OF ANALYSIS}

As regards the analysis of air accidents, reference should be made to the basic concepts adopted in this area. Thus, in accordance with Annex 13 of the Convention on International Civil Aviation, signed in Chicago on 7 December 1944. - Chicago Convention [18], an air accident is an occurrence associated with the operation of an aircraft which, in the case of a manned aircraft, occurs between the time any person boards the aircraft with the intent to fly and the time that the person disembarks. In the case of an unmanned aerial vehicle, however, such an occurrence is assessed from the moment the aircraft is ready to move in order to perform a flight until it comes to a halt at the end of the flight and the moment the propulsion system is switched off, where:

a) a person on board an aircraft is fatally or seriously injured as a result of:

- being on board an aircraft, or

- direct contact with any part of the aircraft, including parts that have been detached from the aircraft, or

- a direct blast of an aircraft engine, except when the injuries are from natural causes, self-inflicted or inflicted by other persons, or when a person is injured hiding outside the areas normally accessible to passengers or crew members, or

b) the aircraft sustains damage or structural failure that endangers its structural durability, performance or control characteristics and would normally require major repair or replacement of the damaged component, except for engine failure or damage, where the failure is limited to the engine itself (including its covers or accessories), propellers, wing tips, antennas, probes, vanes, tires, brakes, wheels, fairings, panels, landing gear flaps, wiper blades, aircraft covering (such as small dents or holes) or minor damage to the main rotor blades, tail rotor blades, landing gear, and those caused by hail or bird strike (including holes in the radio locator antenna casing), or

c) the aircraft is missing or completely inaccessible. 
Note 1. Only in the interests of uniformity of statistics, an injury causing death within 30 days of the occurrence of an accident shall be classified by ICAO as a fatal injury.

Note 2. An aircraft is considered missing if the wreck is not located and the official search is closed.

\section{Classification of causes of accidents}

Only the main cause of the accident was taken into account in the statistical analysis. Where the State Commission on Aircraft Accidents Investigation (SCAAI) gave, for example, two main reasons, the more significant one was used for the analysis. Initially, accidents were classified by the general cause into four categories: those caused by human factors, technical problems, bad weather or other causes. In the next part of the paper, attention was paid to subcategories of the human factor, distinguishing nine areas concerning both the pilots themselves and the control or maintenance staff, such as: poor assessment of the situation, distraction, excessive self-confidence, communication problems, the psychophysical condition, non-compliance with procedures and competition. Despite the fact that according to the "Swiss Cheese Model" created by James Reason (fig. 4) the occurrence of an aviation accident requires a combination of different factors at different levels of management and operation, on the basis of the reports examined, one factor seems to dominate over the others in terms of responsibility for the accident $[7,13]$. The State Commission on Aircraft Accidents Investigation (SCAAI) conducts investigations and records of all events, incidents and air accidents that occurred in the territory of the Republic of Poland or abroad, but due to the Polish national affiliation of the aircraft were reported for investigation at the SCAAI. In this paper, the analy- sis of SCAAI reports on accidents that occurred in the period from 1 January 2010 to 31 December 2015 was performed.

The analysis included 210 civil air accidents that occurred in the Polish airspace and which were investigated by the State Commission on Aviation Accidents Investigation. The causes of these accidents have been classified into the following categories: the so-called human factor, technical cause, meteorological cause and others.

Analyzing the role of the human factor in the literature $[1,2,4,5,6,8,13,14,17,19]$, the most frequently pointed to errors related to: poor assessment of the situation, lack of knowledge, non-compliance with aviation standards and procedures, excessive self-confidence, problems with the transfer of information between crew members or ground control and flight organization services, and factors related to the desire to compete, occurring during air shows and competitions.

\section{RESULTS}

Out of all 210 analyzed reports published by the State Commission on Aviation Accidents Investigation, the largest number of them concerned aircraft (57), then gliders (49) and parachutes (42) (tab. 1). Such a distribution is obvious and very similar throughout the world, mainly due to the popularity of the form of air transport in question. On the other hand, on motor gliders and para gliders, the accidents of which constitute only $1 \%$ of all air accidents, constitute the lowest number of air operations taking place in Poland [5].

There is no information available on the detailed characterization of the psychological characteristics and the individual suitability to fly on different aircraft. For this reason, advanced sta-

Tab. 1. Aviation accidents investigated by the State Commission on Aircraft Accidents Investigation (SCAAI) in Poland, 2010-2015 [9].

\begin{tabular}{|c|c|c|c|c|c|c|c|c|}
\hline Aircraft type & 2010 & 2011 & 2012 & 2013 & 2014 & 2015 & 2010-2015 & Percentage \\
\hline GLIDER & 7 & 5 & 3 & 4 & 14 & 16 & 49 & $24 \%$ \\
\hline PARACHUTE & 3 & 3 & 10 & 4 & 22 & 1 & 43 & $21 \%$ \\
\hline PARAGLIDER & 5 & 3 & 4 & 4 & 2 & 0 & 18 & $9 \%$ \\
\hline HELICOPTER & 3 & 0 & 0 & 3 & 1 & 0 & 7 & $3 \%$ \\
\hline GYROCOPTER & 1 & 0 & 0 & 0 & 0 & 4 & 5 & $2 \%$ \\
\hline BALLOON & 0 & 0 & 1 & 2 & 1 & 0 & 4 & $2 \%$ \\
\hline
\end{tabular}

16 | 2018 | Volume 24| Issue 2 | 
tistical analyses cannot be carried out, nor can detailed assessments of the impact of individual predispositions on critical events resulting in accidents or air accidents be made.

Table 2 presents an initial breakdown of the causes of air accidents in Poland between 2010 and 2015 into four basic categories: human factor, technical defects, bad weather conditions and others. The human factor ranks first with $80 \%$ of all accidents. Unfortunately, the published SCAAI reports, probably due to the provisions of the act on personal data protection, do not provide detailed information allowing to precisely describe the personal characteristics of the persons who contributed to the unreliable operation, and which in consequence led to a situation extremely dangerous for the aviation mission.

Tab. 2. The main causes of the aviation accidents investigated by the State Commission on Aircraft Accidents Investigation (SCAAI) in Poland, 2010-2015 [9].

\begin{tabular}{lcc}
\hline Cause of the air accident & Number of accidents & Percentage \\
\hline HUMAN FACTOR & 160 & $80 \%$ \\
\hline TECHNICAL FAILURES & 32 & $16 \%$ \\
\hline BAD WEATHER CONDITIONS & 7 & $3 \%$ \\
\hline OTHER & 2 & $1 \%$ \\
\hline Total & $\mathbf{2 0 1}$ & $\mathbf{1 0 0 \%}$ \\
\hline
\end{tabular}

In turn, table 3 shows the percentage of human factor in all causes of accidents on a given type of aircraft. It is clear that for more advanced vehicles, such as gliders and airplanes, the human factor is the vast majority of the causes of accidents. Balloons or old types of helicopters had to deal with great technical problems. In addition, the balloon as a means of transport is highly weather dependent, so the main cause of accidents involving this type of aircraft in more than half of the cases was other than human negligence.

Tab. 3. Percentage of the human factor as the cause of air accidents on a given type of aircraft in Poland, 2010-2015 [9].

\begin{tabular}{ll}
\hline Aircraft type & Percentage \\
\hline GYROCOPTER & $100 \%$ \\
\hline GLIDER & $88 \%$ \\
\hline PARAGLIDER & $88 \%$ \\
\hline PARACHUTE & $87 \%$ \\
\hline AIRPLANE & $77 \%$ \\
\hline MOTOR GLIDER & $73 \%$ \\
\hline MOTOR PARAGLIDER & $67 \%$ \\
\hline HELICOPTER & $43 \%$ \\
\hline BALLOON & $25 \%$ \\
\hline
\end{tabular}

Table 4 presents the results of the analysis of reports in which the human being was the basis of the accident and the division of these causes into subcategories. It was possible to clearly distinguish 7 areas in which the human factor was revealed. These were: poor assessment of the situation, distraction, overconfidence, poor psychophysical condition, non-compliance with procedures or a tendency to compete, ineffective communication between crew members and with the organization and flight control services [5].

Tab.4. Percentage of the human factor in the aviation accidents investigated by the State Commission on Aircraft Accidents Investigation (SCAAI) in Poland, 2010-2015 [9].

\begin{tabular}{lcc}
\hline Human factor & Number of accidents & Percentage \\
\hline $\begin{array}{l}\text { POOR ASSESSMENT OF THE } \\
\text { SITUATION }\end{array}$ & 62 & $39 \%$ \\
\hline DISTRACTION & 19 & $12 \%$ \\
\hline OVERCONFIDENCE & 30 & $19 \%$ \\
\hline $\begin{array}{l}\text { COMMUNICATION PRO- } \\
\text { BLEMS }\end{array}$ & 4 & $3 \%$ \\
\hline $\begin{array}{l}\text { BAD PSYCHOPHYSICAL } \\
\text { CONDITION }\end{array}$ & 24 & $15 \%$ \\
\hline $\begin{array}{l}\text { NON-COMPLIANCE WITH } \\
\text { PROCEDURES }\end{array}$ & 16 & $10 \%$ \\
\hline TENDENCY TO COMPETE & 5 & $3 \%$ \\
\hline Total & $\mathbf{1 6 0}$ & $\mathbf{1 0 0} \%$ \\
\hline
\end{tabular}

\section{Analysis of the causes of air accidents}

Among the accidents analyzed for the period 2010-2015, most of them were caused by the human factor, which accounted for $80 \%$ of all accidents. Another important factor was technical reasons (16\%) and atmospheric conditions (2\%). Among the human factors, 39\% accounted for the inability of the pilot to assess the situation or the lack of appropriate skills, which in 21 out of 62 cases was related to very little experience of the pilot or pilotstudent, and in 5 cases to fatigue. The main causes of air accidents among the human factor are: excessive self-confidence of the pilot (19\%), bad psychophysical condition - $15 \%$ ( 15 out of 24 cases 15 are stressrelated), distraction (12\%), non-compliance with procedures $(10 \%)$, and the competition factor (3\%) and communication problems (3\%).

The results show very clearly that the average percentage of the human factor in the causes of air accidents in Poland in the six-year period between January 1, 2010 and December 31, 2015 was at $80 \%$, which does not differ from world standards. The number of accidents per number of air operations on a given type of aircraft is also standard compared to global data. In the analyzed reports, the most common cause of air accidents in the human factor group was poor assessment of the situation (39\%), excessive self-confidence 
(19\%) and poor psychophysical condition (15\%) $[4,5,8,19]$.

A poor assessment of the situation is a cause closely related to little experience. In 28 out of 62 cases, the operator had less than 150 hours of experience with a given type of aircraft or no authorization at all. In the next 5 out of 62 cases, the poor assessment of the situation was caused by fatigue, which is also associated with improper psychophysical condition of the operator. The solution to the problem of insufficient experience is primarily the individual extension of the training period with an instructor [18].

Another risk factor was excessive self-confidence, which led to the omission of checklists in 9 out of 30 cases and bravado in 7 cases. Such behavior was most common in pilots with relatively little experience ( 150 to 500 flight hours) or in very experienced pilots (more than 5000 flight hours). In the first group, this is due to a particularly young age and relatively fast progress in training, in the initial phase, which can give a false sense of selfconfidence. In the case of experienced pilots, excessive self-confidence is the result of routine and hitherto mostly accident-free aviation activity.

In both groups, it is important to make operators aware of the possible misconceptions associated with different hazards, both in flight and on the ground, and to check their knowledge of procedures and working in accordance with them $[2,4,6]$.

In the third most common subcategory, stress came first, contributing to $67 \%$ of all accidents categorized as being caused by poor physical and mental health. Delayed reaction, often associated with fatigue, ranked second, and about $10 \%$ of these accidents were caused by the operator's medication or illness. Stress is a well-known factor these days. There are many ways to deal with stress, and even training in stress management techniques, which allow for quick coping, is being introduced.

In the case of recreational aviation, an operator who is not in good psychological and physical condition can easily opt out of planned activities in the air. On the other hand, government or commercial aviation employees often conceal the inadequate condition of their bodies and expose themselves and others to danger. In this case, employers play an important role, as they should have safety friendly policies and, in cases of chronic stress of their employees or other problems in their private lives, provide them with appropriate leave or dismissal. This category also includes alcohol, under the influence of which the operators performed flight operations. It is obvious that every narcotic drug impairs the nervous system of the human body, affecting the speed of reaction and the ability to perceive the situation. In such a situation, for legal reasons, the State Commission on Aircraft Accidents Investigation has the right not to investigate an accident of an aircraft whose operator was under the influence of narcotic drugs, which may also distort the analysis statistics $[3,4,8,19]$.

Other dangerous factors taken into account in this paper were: distraction (caused 12\% of accidents in the human factor category) and insubordination to regulations (10\%). Visual distraction was often associated with poor psychophysical condition, but was distinguished as a separate factor due to the fact that it was even more associated with the operator's experience. The frequency of distraction among operators is similar to the distribution of complacency. Pilots with little experience often misjudge the situation or make other mistakes, but remain fully focused. Pilots with extensive experience and those with 150-500 flight hours can be exposed to distraction. Such a division also occurs in the case of insubordination to regulations. The rarest problems were communication problems and willingness to compete (each factor with a share of $3 \%$ ). This distribution is extremely simple to explain. Air transport has been unified by standard phraseology, which allows for a clear exchange of information even in case of problems with the radio, and competitiveness occurs basically only during air competitions, which constitute a very small percentage of all air operations conducted in the Republic of Poland $[2,3,6,8,19]$.

\section{DISCUSSION}

The main objective of the above paper was to analyze the sources of air accidents that occurred in Polish civil aviation in the years 2010-2015, with particular emphasis on human participation in the causes of accidents. In the paper, a new method of division of human factor causes was applied, which in the future may facilitate the orientation of aviation training or qualification verification in relation to groups of operators threatened by a given factor. The above analysis is also a source of knowledge for the operators themselves, explaining what they should pay special attention to.

As regards helicopter accidents, in 2016, statistics were published that highlighted the problem of a greater number of helicopter accidents caused by technical issues than accidents involving airplanes. Moreover, research conducted since the 1970s and published at the first International Symposium on Helicopter Safety shows that the 
number of helicopter accidents was 43 times higher than the number of airplane accidents [16].

However, trends in the causes of air accidents have changed enormously over the years. Thus, the Billings and Reynard paper [4] on the human factor in aviation incidents from October 1985 states that more than half of all events were caused by the human factor [8]. Moreover, the most frequent factors connected with unreliable functioning of a human being were: incorrect decision-making processes, incorrect management of cockpit resources, boredom, excessive self-confidence and tiredness. Therefore, these problems were of interest to psychologists and flight training organizers. CRM (Crew Resource Management) training programmes have been developed, teaching pilots how to cooperate in a team. At present, extensive procedures and lists adapted even to emergency situations are used to evaluate decision-making processes in commercial aviation.

However, the most difficult to assess is the influence of factors related to personality traits and current psychophysical status on unreliable action in extreme situations [8]. This is due to the fact that for over a dozen years now, in the periodic examination of aviation personnel, no assessment of the personality and current operator skills (perception, motor, psychophysical) of airline pilots, flight attendants or flight security personnel has been carried out. Until the end of the 1990s, however, during periodic examinations, psychological examination, in addition to medical examination, was a sine qua non for decision-making by an aviation and medical commission and the issuing of a certificate on the current state of health, which determined the continuation of work in aviation professions. At that time, periodic medical examinations for airline pilots were conducted every six months, while other crew members were subject to mandatory examinations by the aviation and medical commission every three years. The current legal regulations are very liberal as regards the assessment of individual predispositions to perform aviation professions and boil down to medical examinations conducted by authorized medical practitioners within the framework of individual medical practice. However, only 1st class pilots are examined by aviation and medical commissions and subjected to the certification procedure in the Aeronautical Medicine Centers authorized by the Chief Medical Officer of the Civil Aviation Authority.

Moreover, it should be stressed that in the near future the human factor can be largely eliminated or minimized by replacing many of the activities currently performed by the pilot by systems controlled by artificial intelligence, which will effectively support human decision making during the control of aircraft.

\section{CONCLUSIONS}

In the Polish airspace, as in the entire world, the percentage of human factor in aviation disasters was reduced to $80 \%$. Among the causes related to the human factor, the following are still dominating"

- the lack of ability to correctly assess the situation due to lack of professional experience,

- the bravado of pilots and their poor psychophysical condition.

In addition, the psychophysical condition and current fitness of flight crews should be monitored more precisely by means of organizational and legislative measures including:

- introduction of psychological assessment during periodical examinations carried out at Aeronautical Medicine Centers,

- introduction of psychological assessment during periodical examinations performed by authorized medical practitioners within the framework of individual medical practice.

The substantive problem of the above mentioned organizational activities is also the qualifications of psychologists performing the tasks of certification of aviation personnel. At present, there are no legal regulations or specialist centers providing training in this field. There is a lack of psychologists with knowledge and experience in the field of procedures and rules for investigating incidents and accidents and air disasters.

There are no such specialists in civil aviation, and there are only two people left in the structures subordinate to the Ministry of National Defense who could undertake such tasks in order to transfer knowledge in this area and provide substantive preparation for such tasks.

\section{AUTHORS' DECLARATION:}

Study Design: Justyna Skrzyńska, Zdzisław Kobos, Zbigniew Wochyński; Data Collection: Justyna Skrzyńska, Zdzisław Kobos, Zbigniew Wochyński; Manuscript Preparation: Justyna Skrzyńska, Zdzisław Kobos, Zbigniew Wochyński; Funds Collection: Justyna Skrzyńska, Zdzisław Kobos, Zbigniew Wochyński. The Authors declare that there is no conflict of interest. 


\section{REFERENCES}

1. Badania Thomasa G. C. Griffina, https://www.researchgate.net/scientific-contributions/16401142_TGC_Griffin.

2. Beaty D. Pilot. Naga prawda. Czynnik ludzki w katastrofach lotniczych. Wydawnictwo W.A.B., Warszawa 2013.

3. Billings CE, Demosthenes T, White TR, O'Hara DB. Effects of alcohol on pilot performance in simulated flight. Aviation Space Environment Med. 1991; 62(3):233-235.

4. Billings CE, Reynard WD. Human factors in aircraft incidents: results of a 7-year study. Aviation Space Environment Med. 1984; 55(10):960-965

5. Dąbrowska J. Czynnik ludzki w lotnictwie. Prace Instytutu Lotnictwa. Warszawa 2011; 12(221):66-70.

6. Gore BF. Minimizing Human Risk: Human Performance Models in the Space Human Factors and Habitability and Behavioral Health and Performance Elements, In the 7th International Conference on Applied Human Factors and Ergonomics (AHFE). Orlando, FL, United States, 27-31 Jul. 2016.

7. Griffin TGC, Young MS, Stanton NA. Human factors models for aviation accident analysis and prevention. Ashgate Publishing Company, Burlington, USA, 2015.

8. Kałużna E, Fellner A. Metody uwzględniania czynnika ludzkiego w zarządzaniu bezpieczeństwem systemu transportu lotniczego. Oficyna Wydawnicza Politechniki Warszawskiej. 2014; 103:99-111.

9. Komunikaty Państwowej Komisji Badania Wypadków Lotniczych, https://www.gov.pl/web/infrastruktura/szukaj?query=komunikaty\&page $=1$.

10. Krause SS. Aircraft Safety. Accident Investigations, Analyses \& Applications, McGraw-Hill Education (2nd Ed.), New York 2003.

11. Program zapobiegania wypadkom. Wprowadzenie do wyroku pilotażowego, http://www.sjflight.com/images/pilot_judgment. pdf.

12. Raporty z badań wypadków lotniczych publikowane na stronie Państwowej Komisji Badania Wypadków Lotniczych, https:// www.gov.pl/web/infrastruktura/panstwowa-komisja-badania-wypadkow-lotniczych.

13. Reason J. Human error. Cambridge University Press, 1990.

14. Reason J. Managing the Risks of Organisational Accidents (1997), http://www.safetyleaders.org/superpanel/superpanel_james_reason.html.

15. Shappell SA, Wiegmann DA. The Human Factors Analysis and Classification System-HFACS, U.S. Department of Transportation, Federal Aviation Administration. Final Report. DOT/FAA/AM-00/7. Washington 2000.

16. Statystyki bezpieczeństwa lotniczego w UE. Eurostat. Statistics Explained, http://ec.europa.eu/eurostat/statistics-explained/ index.php/Air_safety_statistics_in_the_EU.

17. Terelak JF. Człowiek w sytuacji pracy w okresie ponowoczesności, Wydawnictwo UKSW, Warszawa 2012.

18. Urząd Lotnictwa Cywilnego. Załącznik nr 13 do Konwencji o Międzynarodowym Lotnictwie Cywilnym (Konwencja Chicagowska) z dnia 7 grudnia 1944 roku, http://www.ulc.gov.pl/pl/prawo/prawo-międzynarodowe/206-konwencje.

19. Wiener EL, Nagel DC. Human Factors in Aviation - Cognition and Perception, Academic Pres, San Diego 1988.

Cite this article as: Skrzyńska J, Kobos Z, Wochyński Z. Analysis of the Human Factor in Air Accidents in Polish Civil Aviation in the Years 2010-2015. Pol J Aviat Med Bioeng Psychol 2018; 24(2): 11-20. DOI: 10.13174/pjambp.30.10.2019.02 